\title{
Do Small Capital Markets Recognize Differentiated Corporate Governance Structure? Evidence from the Indonesian IPOs
}

\author{
Tanweer Hasan $^{1 *}$, Muliaman Hadad ${ }^{2}$ and Shakil Quayes ${ }^{3}$ \\ ${ }^{1}$ Roosevelt University, Chicago, IL USA \\ ${ }^{2}$ Financial Services Authority, Indonesia \\ ${ }^{3}$ University of Massachusetts Lowell, USA
}

\begin{abstract}
The Capital Market Supervisory Agency in Indonesia and subsequently, the Indonesian Stock Exchange introduced the requirement of appointing at least $30 \%$ commissioners as independent, in the Board of Commissioners, in all public companies by December 31, 2001. The present study documents the extent of compliance of this new requirement and investigates whether the capital market can recognize the IPO firms that are in compliance from those that are not, using a sample of 72 IPO firms in Indonesia over the period 2002 through 2007. Results from the multivariate analysis indicate that IPO firms that are in compliance do experience significant less underpricing compared to those that are not. Furthermore, a positive, but insignificant, relationship between compliance and postIPO firm valuation is reported in the present study. The results documented in this study should be comforting to the policy makers in Indonesia, as well as other developing countries, in that governance reform measures do work without necessarily having a pre-existing strong legal system.
\end{abstract}

Keywords: Capital market; Commissioners; Compliance; Governance; Multivariate analysis; Policy makers; Stock exchange

\section{Introduction}

The market-based corporate governance model postulates that good corporate governance helps companies to increase share price and makes it easier to obtain external capital. Specifically institutional and foreign investors would hesitate to invest in companies that do not subscribe to good corporate governance principles. Transparency, independent directors and a separate audit committee are especially important corporate governance measures.

Policy makers in developing countries, with the help and dictate of donor agencies, have been pursuing an aggressive agenda of reform at both macro (regulatory/legal) and micro (institutional/firm-specific) levels to ensure good corporate governance over the last two decades. Indonesia has embarked on this reform path since the early 90s, more specifically after the Asian financial crisis (1997-1999) as poor corporate governance has been cited as a key factor in this crisis. One fundamental underlying assumption of good governance system is the existence of a strong legal system/culture and consequently, there are concerns about the governance reform models, in terms of their efficacy and applicability, in the context of many developing countries. Specifically, given the state (relative inefficiency) of civil and criminal justice system, critics continue to express concern whether the corporate governance reforms pursued over the decades in Indonesia, with the help and dictate of various donor agencies, is working effectively or not.

Companies in Indonesia have a two-tier board system - Board of Directors (BOD) and Board of Commissioners (BOC). The BOD is responsible for running the daily activities of a company while the BOC supervise and advise the BOD. As a quick response to the Asian financial crisis The National Committee for Corporate Governance (KNKGC) was formed in August 1999 which, in turn, recommended (in 2000) a list of guidelines aimed at promoting good governance. Since then several major regulatory reform initiatives have been taken by The Capital Market Supervisory Agency (BAPEPAM) to enhance governance standards which include rules regarding independent directors and independent commissioners. Particular attention is paid to BOC in the discussion of corporate governance in Indonesia as professional commissioners are essential prerequisites for higher standards. The functions of the independent commissioners are similar to the non-executive members of the board under the one-board system. The BOC, in Indonesia, has the right to suspend the entire BOD and temporarily assume management control until a new BOD is appointed. The BOC is expected to establish an audit committee which, in turn, oversees the firm's financial reporting process. An independent member of the BOC serves as chair of the audit committee.

To complement BAPEPAM rules BEJ (PT Bursa Efek Indonesia, Jakarta - The Stock Exchange) also issued similar rules for listed companies with a compliance deadline of December 31, 2001 at the latest. One requirement in particular, among others, calls for listed companies to have, at least, one director in the BOD to be unaffiliated and, at least, $30 \%$ of the BOC members to be independent (Decision Letter of BEJ No.: Kep-315/BEJ/06-2000, which was later amended by Decision Letter No.: Kep-339/BEJ/07-2001). To qualify as an independent commissioner, the stock exchange regulation requires, among other things, that the person must have no 'affiliation' with the controlling shareholder or any other director or commissioner of the listed company.

Three previous studies looked into Indonesian IPO underpricing (in a single-country context) but all of them were written in the local language (Bahasa Indonesia) - Hanafi [1] covered the period 1989-1994, Ali and Hartono [2] used a sample period 1994-1999, and Suherman [3] used the period from 2004 through 2007. Indonesian IPOs were also included in two, multi-country, IPO studies written in English -

*Corresponding author: Tanweer Hasan, Roosevelt University, Chicago, IL USA E-mail: thasan.ru@gmail.com

Received October 16, 2014; Accepted November 13, 2014; Published November 19,2014

Citation: Hasan T, Hadad M, Quayes S (2014) Do Small Capital Markets Recognize Differentiated Corporate Governance Structure? Evidence from the Indonesian IPOs. J Account Mark 3: 119. doi: 10.4172/2168-9601.1000119

Copyright: $\odot 2014$ Hasan T, et al. This is an open-access article distributed under the terms of the Creative Commons Attribution License, which permits unrestricted use, distribution, and reproduction in any medium, provided the original author and source are credited. 
Ljungqvist and $\mathrm{Yu}$ [4] uses a sample period from 1995 through 2001, and Boulton, Smart and Zutter [5] uses the period 2000-2004. While the empirical IPO literature, in general, is mature with the stylized facts established and most theories have been subjected to empirical testing, using IPO data from around the globe, the literature on the relationship between good corporate governance measures and IPO underpricing/ post-IPO firm valuation is relatively new. Given the past research the present study is, probably, the most comprehensive study done on the Indonesian IPOs since the Asian financial crisis (1997-1999) and the very first study to assess the effectiveness of corporate governance reforms undertaken in Indonesia, specifically since the crisis, using IPO data.

The present study documents the extent of compliance of this new requirement for companies to have at least $30 \%$ of BOC members as independent and investigates whether the capital market can recognize the IPO firms that are in compliance from those that are not, using a sample of 72 IPO firms in Indonesia over the period 2002 through 2007. Results from the multivariate analysis indicate that IPO firms that are in compliance do experience significant less underpricing compared to those that are not. Furthermore, a positive, but insignificant, relationship between compliance and post-IPO firm valuation is reported in the present study.

The remainder of the paper is organized as follows. The data and methodology used along with the hypotheses tested in the present study are delineated in Section 2. The empirical results and corresponding analysis are presented in Section 3. Section 4 contains summary and concluding remarks.

\section{Data, Hypotheses and Methodology}

\section{Data}

IPO prospectuses were collected directly from the Indonesian Stock Exchange. Relevant stock prices were collected from Bloomberg database. A total of 72 IPO firms, over the period January 2002 through December 2007, are included in the final sample. The starting point for the sample period is obvious as the $\mathrm{BEJ}$ regulation on the required percentage of independent commissioners on the BOC had a compliance deadline of December 31,2001. During the later part of 2007 the Indonesian government promulgated Law No. 40 of 2007 on limited liability companies as a successor to Law No. 1 of 1995 . This 2007 promulgation contains, among other things, expanded and new scopes and responsibilities for the BOC. Per the Article 120 Paragraph 1 of Law No. 40 of 2007 there might be now three types of commissioners in a company - ordinary commissioners, independent commissioners and delegated commissioners. However, the role and duties of delegated commissioners are not delineated except that Article 120 Paragraph 4 simply states that their roles would be specified in the company's Article of Association. This new concept of delegated commissioners has, as seen by some, blurred the difference between BOC from the BOD [6]. Consequently, the sample period of the present study ends in 2007.

\section{Hypotheses}

$\mathrm{H}_{1}$ : IPO firms that meet or exceed the requirement, of appointing at least $30 \%$ of the commissioners of the BOC as independent, experience lower underpricing.

$\mathrm{H}_{2}$ : IPO firms that meet or exceed the requirement, of appointing at least $30 \%$ of the commissioners of the BOC as independent, experience higher post-IPO market valuation.

\section{Calculation of underpricing}

The day 1 underpricing for each IPO is calculated as:

$\mathrm{UP}=\left[\left(\mathrm{P}_{\mathrm{t}}-\mathrm{P}_{0}\right) / \mathrm{P}_{0}\right] \times 100$

where,

$\mathrm{P}_{\mathrm{t}}=$ stock price in secondary market at time $\mathrm{t}$

$\mathrm{P}_{0}=$ offer price of the stock

\section{Impact of compliance on underpricing}

To capture the impact of complying with the requirement of having at least $30 \%$ Independent Commissioners in the BOC on IPO underpricing, if any, a multivariate model is estimated as follows:

$\mathrm{UP}=\alpha_{0}+\beta_{1} \mathrm{CLVL}+\beta_{2} \mathrm{AGE}+\beta_{3} \mathrm{IOP}+\beta_{4} \mathrm{LSIZE}+\beta_{5}$ PCTPUB + $\mathrm{B}_{6} \operatorname{AUDREP}+\varepsilon$

where,

$\mathrm{UP}=$ Day 1 underpricing calculated using equation (1)

CLVL = Compliance level; dummy variable; 1 if the BOC has at least 30\% Independent Commissioners, 0 otherwise

AGE $=$ Age of the firm

IOP $=1$ over offer price of the IPO

LSIZE $=$ Log of size of the company in the year before going public

PCTPUB $=$ Percent of the total shares offered to public

AUDREP = Auditor's reputation; dummy variable; 1 if BIG 5/4, 0 otherwise

The appointment of at least $30 \%$ of the BOC as independent commissioners can be viewed as a signal of good governance practice in IPO and may reduce the uncertainty associated with investing in Indonesian IPOs which are, in general, controlled by various families. Therefore, Firms meeting or exceeding the BOC relevant rule (CLVL) may be able to obtain a better offer price and consequently, experience less underpricing. The variables AGE, IOP, LSIZE, PCTPUB, and AUDREP are picked based on the asymmetric-information models of IPO underpricing and used as control variables. AGE is calculated as the difference, in years, between the year an IPO is issued and the year the IPO firm started its operations. The longer a firm has been around the less the uncertainty is, in the mind of investors, about its IPO valuation $[7,8]$. A firm with longer history will generate more interest among investors and those who did not get the shares at the time of IPO would like to acquire them after trading starts in the secondary market - resulting in greater underpricing. Log of sales in the year prior to IPO is used a proxy for size (LSIZE) of the IPO firm. Smaller firms may have more uncertainty and be more speculative than larger firms. Consequently, an inverse relationship between size and underpricing can be expected. A higher percentage of insider/family ownership of the firm may signal to the market that the firm is of high quality and reduce investor's uncertainty. Therefore, a lower PCTPUB may be taken to indicate greater insider confidence in the future prospect of the firm [9-13] and result in higher underpricing. The inverse of offer price, IOP, is used as an ex-ante measure of risk of an IPO firm per Tinic [14] who reports that low-priced stocks are often issued by highly speculative firms and the offer price contains critical information about the risk of the IPO. The riskier the IPO firm is the greater the underpricing. A specific way to reduce the informational asymmetry between informed and uninformed investors is to hire a reputable auditor. By agreeing to 
be associated with an offering, reputable auditors effectively "certify" the quality of the issue. Therefore, we expect IPO firms engaging reputable accounting firms (BIG 5/4), AUDREP, to audit their financial statements to experience lower underpricing.

\section{Relationship between compliance and post-IPO firm valuation}

Post-IPO firm valuation is as measured as the market to book value ratio at different intervals and is calculated as:

$\mathrm{MBV}_{\mathrm{t}}=\left(\mathrm{P}_{\mathrm{t}} \times \mathrm{Vol}_{\mathrm{t}}\right) / \mathrm{SE}_{-1}$

where,

$\mathrm{MBV}_{\mathrm{t}}=$ Market to book value ratio at time $\mathrm{t}$

$\mathrm{P}_{\mathrm{t}}=$ Closing price of the firm stock at time $\mathrm{t}$

$\mathrm{Vol}_{\mathrm{t}}=$ Volume of trading at time $\mathrm{t}$

$\mathrm{SE}_{-1}=$ Stockholders Equity in the year preceding IPO issue

$\mathrm{t}=$ Day 1 and calendar months 1 and 3

IPO firms that meet or exceed the requirement, of appointing at least $30 \%$ of the commissioners of the BOC as independent, are separated from those that do not. If the capital market recognizes the differentiated governance structure of the IPO firms, market to book value ratios at various intervals (day 1 , months 1 and 3) can be expected to be higher in the former subsample. The multivariate model used is as follows:

$\mathrm{MBV}_{\mathrm{t}}=\alpha_{0}+\beta_{1} \mathrm{CLVL}+\beta_{2}$ AGE $+\beta_{3} \mathrm{IOP}+\beta_{4} \mathrm{LSIZE}+\beta_{5}$ PCTPUB $+\beta_{6}$ AUDREP $+\varepsilon$

\begin{tabular}{|c|c|c|c|c|}
\hline Variable & Mean & $\begin{array}{c}\text { Standard } \\
\text { Deviation }\end{array}$ & Minimum & Maximum \\
\hline UP (\%) & 27.19 & 27.06 & -32.59 & 70.00 \\
\hline Par/Nominal Value (Rp.) & 182.64 & 137.68 & 100.00 & 500.00 \\
\hline Offer Price (Rp.) & 459.44 & 491.50 & 105.00 & 2340.00 \\
\hline
\end{tabular}

Table 1: Simple IPO Statistics: 2002-2007.

\begin{tabular}{|c|c|c|c|}
\hline Year & Number of IPOs & Mean UP (\%) & $\begin{array}{c}\text { Mean Gross Proceeds } \\
\text { (in billion Rp.) }\end{array}$ \\
\hline 2002 & 18 & 29.69 & 56.86 \\
\hline 2003 & 6 & 13.64 & 1195.04 \\
\hline 2004 & 11 & 17.89 & 127.59 \\
\hline 2005 & 7 & 15.56 & 482.15 \\
\hline 2006 & 11 & 30.35 & 284.56 \\
\hline 2007 & 19 & 36.93 & 707.07 \\
\hline
\end{tabular}

Table 2: Day 1 Underpricing (UP) and Gross Proceeds by Year: 2002-2007.

\begin{tabular}{|c|c|c|c|}
\hline $\begin{array}{c}\text { Industry } \\
\text { Group \# }\end{array}$ & Industry Name & $\begin{array}{c}\text { Number of } \\
\text { IPOs }\end{array}$ & UP (\%) \\
\hline 1 & Agriculture & 5 & 52.60 \\
\hline 2 & Mining & 7 & 34.34 \\
\hline 3 & Basic Industry and Chemicals & 3 & 13.56 \\
\hline 4 & Miscellaneous Industry & 3 & 6.73 \\
\hline 5 & Consumer Goods Industry & - & - \\
\hline 6 & $\begin{array}{c}\text { Property, Real Estate and Building } \\
\text { Construction }\end{array}$ & 10 & 40.08 \\
\hline 7 & Infrastructure, Utilities and & 10 & 22.28 \\
\hline 8 & Transportation & 21 & 20.92 \\
\hline 9 & Frade, Services and Investment & 13 & 25.41 \\
\hline
\end{tabular}

Table 3: Mean Day 1 Underpricing (UP) by Industry Groups: 2002-2007. where, the variable $\mathrm{MBV}_{\mathrm{t}}$ is same as in equation (3) and the variables CLVL, AGE, IOP, LSIZE, PCTPUB and AUDREP are the same as in equation (2). Again, if the market recognizes the differentiated governance structure of the IPO firms it can be expected that the firms that meet or exceed the requirement, of appointing at least $30 \%$ of the commissioners of the BOC as independent, will have a higher market to book value ratio at different intervals of time in the post IPO periods (at the end of day 1 as well as months 1 and 3 ) compared to those firms that do not.

\section{Analysis and Results}

An investigation of the prospectuses reveals that more than one third of the IPO firms, 26 out of total 72 or (36\%), either failed to specifically indicate in the prospectus that they are in compliance or did not meet the requirement of keeping at least $30 \%$ of the commissioners in the BOC as independent. Table 1 provides simple statistics on Indonesian IPOs (Table 1). While the mean nominal/par value of IPO stocks was Rp. 182.64 and ranged from Rp. 100 to Rp. 500 the mean offer price was Rp. 459.44 and ranged from Rp. 105 to Rp. 2340. The average day 1 underpricing for the sample period $2002-2007$ was $27.19 \%$ with the maximum at $70 \%$.

Table 2 shows the mean day 1 underpricing and the gross proceeds from IPO issue by year. The largest amount, Rp. 1195 billion, was raised in 2003 followed by Rp. 707 billion in 2007. The smallest amount, Rp. 56.86 billion, was raised in 2002. The year 2007 witnessed the highest underpricing, $36.93 \%$, followed by year $2006,30.35 \%$. The lowest mean underpricing, $13.64 \%$, was recorded in 2003 . The mean day 1 underpricing by industry groups is reported in Table 3. IPO firms belonging to the Agriculture sector experienced the largest underpricing, $52.60 \%$ followed by firms in the Property, Real Estate and Building Construction Industry, 40.08\%. IPO firms in the Miscellaneous Industry Category experienced the lowest mean underpricing, $6.73 \% .{ }^{1}$ While Table 4 provides descriptive statistics for all the variables included in the two multivariate models used in the present study Table 5 provides the correlation matrix for the same. The average age of the IPO firm is 21.18 years and ranged from a low of 3 years to a whopping 108 years. Financial statements, included in the prospectuses, of $38 \%$ of the sample firms were audited by reputable accounting firms (BIG 5/4). On the average, $26 \%$ of the firm's total shares were offered to general public. Given the correlation coefficients reported in Table 5 the variance inflation factors (VIF) were checked for each multivariate model, as reported later in Tables 6 and 8 , and the VIFs were found to be all below 2 .

The results from the first multivariate model looking into the impact of compliance of BOC rules regarding independent commissioners on underpricing are reported in Table 6 . The coefficient of the compliance variable, CLVL, showed up as statistically significantly negative, at $5 \%$ level, lending support to the null hypothesis $1\left(\mathrm{H}_{1}\right)$. This means the IPO firms that comply with BEJ requirements of appointing $30 \%$ or more commissioners in the BOC as independent experience lower underpricing compared to the firms that do not. Coefficients of two control variables, IOP and AUDREP, showed up as statistically significant with positive and negative signs respectively. This means the higher the ex-ante risk of the IPO firms the higher the underpricing. Also, IPO firms that engaged reputable (BIG 5/4) auditors to certify the financial statements, included in the prospectuses, experienced

${ }^{1}$ Miscellaneous Industry is made up of firms that belong to the following groups (1) Machinery and Heavy Equipment, (2) Automotive and Components, (3) Textile, Garment, (4) Footwear, (5) Cable, (6) Electronics and (7) Others. 
Citation: Hasan T, Hadad M, Quayes S (2014) Do Small Capital Markets Recognize Differentiated Corporate Governance Structure? Evidence from the Indonesian IPOs. J Account Mark 3: 119. doi: 10.4172/2168-9601.1000119

Page 4 of 5

\begin{tabular}{|c|c|c|c|c|c|}
\hline Variable & $\mathbf{N}$ & Mean & Standard Deviation & Minimum & Maximum \\
\hline UP & 72 & 27.19 & 27.06 & -32.59 & 70.00 \\
\hline CLVL & 72 & 0.64 & 0.48 & 0.00 & 1.00 \\
\hline AGE & 72 & 21.18 & 19.75 & 3.00 & 108.00 \\
\hline LSIZE & 72 & 25.74 & 2.31 & 19.45 & 31.09 \\
\hline IOP & 72 & 0.42 & 0.27 & 0.04 & 0.95 \\
\hline AUDREP & 72 & 0.38 & 0.49 & 0.00 & 1.00 \\
\hline PCTPUB & 72 & 0.26 & 0.10 & 0.09 & 0.53 \\
\hline MBVD1 & 72 & 1.15 & 3.64 & -0.04 & 18.96 \\
\hline MBVM1 & 72 & 0.20 & 1.01 & -0.01 & 8.45 \\
\hline MBVM3 & 72 & 0.04 & 0.13 & -0.07 & 0.97 \\
\hline
\end{tabular}

Table 4: Descriptive Statistics: Regression Variables.

\begin{tabular}{|c|c|c|c|c|c|c|c|c|c|c|}
\hline Variable & UP & CLVL & AGE & IOP & LSIZE & PCTPUB & AUDREP & MBVD1 & MBVM1 & MBVM3 \\
\hline UP & 1.00 & -0.17 & 0.04 & $0.48^{*}$ & -0.15 & -0.05 & $-0.31^{*}$ & -0.07 & 0.07 & 0.16 \\
\hline CLVL & 0.17 & 1.00 & -0.02 & 0.09 & 0.05 & 0.08 & -0.01 & -0.03 & 0.07 & 0.16 \\
\hline AGE & 0.04 & -0.02 & 1.00 & 0.00 & $0.33^{\star}$ & -0.12 & 0.09 & -0.17 & -0.10 & -0.15 \\
\hline IOP & $0.48^{*}$ & 0.09 & 0.00 & 1.00 & $-0.45^{*}$ & 0.10 & $-0.34^{*}$ & 0.10 & 0.16 & $0.24^{* *}$ \\
\hline LSIZE & -0.15 & 0.05 & $0.33^{*}$ & $-0.45^{*}$ & 1.00 & $-0.43^{*}$ & $0.47^{\star}$ & $-0.42^{*}$ & $-0.39^{*}$ & $-0.36^{*}$ \\
\hline PCTPUB & -0.05 & 0.08 & -0.12 & 0.10 & $-0.43^{*}$ & 1.00 & $-0.25^{* *}$ & $0.46^{*}$ & $0.21^{* * *}$ & $0.22^{* * *}$ \\
\hline AUDREP & $-0.31^{*}$ & -0.01 & 0.09 & $-0.34^{*}$ & $0.47^{\star}$ & $-0.25^{\star}$ & 1.00 & $-0.20^{* * *}$ & -0.14 & -0.06 \\
\hline MBVD1 & -0.07 & -0.03 & -0.17 & 0.10 & $-0.42^{*}$ & $0.46^{\star}$ & $-0.20^{+* *}$ & 1.00 & $0.56^{\star *}$ & $0.44^{* *}$ \\
\hline MBVM1 & 0.07 & 0.07 & -0.10 & 0.16 & $-0.39^{*}$ & $0.21^{* *}$ & 0.14 & $0.56^{*}$ & 1.00 & $0.83^{*}$ \\
\hline MBVM3 & 0.16 & 0.16 & -0.15 & $0.24^{* *}$ & $-0.36^{*}$ & $0.22^{* * *}$ & -0.06 & $0.44^{*}$ & $0.83^{*}$ & 1.00 \\
\hline
\end{tabular}

'Significant at $1 \%$ level.

"Significant at $5 \%$ level.

** Significant at $10 \%$ level.

Table 5: Correlation Matrix for Regression Variables.

\begin{tabular}{|c|c|}
\hline Variable & Parameter Estimate \\
\hline Intercept & -29.21 \\
& $(-0.54)$ \\
\hline CLVL & $-12.43^{* *}$ \\
& $(-2.14)$ \\
\hline AGE & -0.00 \\
& $(-0.02)$ \\
\hline IOP & $49.89^{*}$ \\
& $(4.23)$ \\
\hline LSIZE & 2.03 \\
& $(1.20)$ \\
\hline PCTPUB & -15.68 \\
& $(-0.53)$ \\
\hline AUDREP & $-12.96^{* *}$ \\
\hline Adjusted R & $(-1.99)$ \\
\hline
\end{tabular}

'Significant at $1 \%$ level.

*Significant at $5 \%$ level.

Table 6: Multivariate Analysis: Impact of Compliance on IPO Underpricing

Model: UP $=\alpha_{0}+\beta_{1}$ CLVL $+\beta_{2}$ AGE $+\beta_{3}$ IOP $+\beta_{4}$ LSIZE $+\beta_{5}$ PCTPUB $+B_{6}$ AUDREP $+\varepsilon$

lower underpricing. The coefficients of all the control variables came up with the expected sign except LSIZE (size or log of sales). However, the coefficient of this variable was statistically insignificant. The adjusted $\mathrm{R}^{2}$ of the regression model was reasonably high, $26 \%$.

Table 7 contains the mean values of some key variables for the firms in the compliance ( 46 firms) and non-compliance ( 26 firms) subsamples along with the difference between the means. While the mean day 1 underpricing is lower for the IPO firms in the compliance subsample compared to those in the non-compliance subsample the offer price and closing prices, at the end of trading on day 1 and calendar months 1 and

3 are higher than the latter group. Also, the mean market to book value ratio of IPO firms measured at the end of trading on day 1 and calendar months 1 and 3 are higher for firms in the compliance subsample compared to those in the non-compliance subsample. However, only the mean market to book value ratio of the firms in the compliance subsample is statistically significantly, at $10 \%$ level, higher compared to those in the non-compliance subsample three calendar months after the IPO firms started trading in the secondary market. While this provided initial support for the null hypothesis $2\left(\mathrm{H}_{2}\right)$ a multivariate model was estimated to check the validity of the result. Results from the multivariate analysis looking into the possible impact of compliance on the market to book value ratio of IPO firms in the post IPO-periods (at the end of trading on day 1 and calendar months 1 and 3 ) are reported in Table 8. The coefficient of the compliance variable, CLVL, is positive in all but the first regression where the dependent variable where the market to book value ratio is measured at the end of day 1 trading. However, the coefficient of CLVL is not statistically significant in any of the three regressions. Therefore, the second hypothesis $\left(\mathrm{H}_{2}\right)$, that the firms in the compliance subsample experience higher market to book value ratios in the secondary market compared to those that do not, cannot be supported. One control variable, size (LSIZE or log of sales), is found to have a statistically significant negative relationship with the market to book value ratios at all 3 time intervals after IPO started trading (day 1 , month 1 and month 3 ). This may be taken to mean that the firms that are already large prior to going public tend to have lower growth potentials in the post-IPO periods.

\section{Concluding Remarks}

The present study documents the extent of compliance to a new requirement of appointing at least $30 \%$ commissioners as independent, in the Board of Commissioners, in all public companies in Indonesia 
Citation: Hasan T, Hadad M, Quayes S (2014) Do Small Capital Markets Recognize Differentiated Corporate Governance Structure? Evidence from the Indonesian IPOs. J Account Mark 3: 119. doi: 10.4172/2168-9601.1000119

Page 5 of 5

\begin{tabular}{|c|c|c|c|}
\hline Variable & $\begin{array}{c}\text { Mean value for firms } \\
\text { in compliance with the } \\
\text { corporate governance } \\
\text { rules on BOC } \\
\mathbf{N = 4 6}\end{array}$ & $\begin{array}{c}\text { Mean value for firms } \\
\text { NOT in compliance } \\
\text { with the corporate } \\
\text { governance rules on } \\
\text { BOC } \\
\mathbf{N = 2 6}\end{array}$ & $\begin{array}{c}\text { Difference in } \\
\text { means } \\
\text { (t-statistic) }\end{array}$ \\
\hline UP (\%) & 23.80 & 33.18 & $\begin{array}{c}-9.38 \\
(-1.34)\end{array}$ \\
\hline OP & 500.11 & 387.50 & $\begin{array}{c}112.61 \\
(1.08)\end{array}$ \\
\hline IOP & 0.44 & 0.39 & 0.05 \\
\hline D1P & 573.76 & 475.84 & $\begin{array}{c}0.86) \\
(0.92 \\
(14)\end{array}$ \\
\hline M1P & 606.98 & 552.73 & $\begin{array}{c}54.25 \\
(0.45)\end{array}$ \\
\hline M3P & 575.30 & 567.58 & $\begin{array}{c}7.73 \\
(0.07)\end{array}$ \\
\hline MBVD1 & 1.07 & 1.28 & $-\begin{array}{c}-0.21 \\
(-0.23)\end{array}$ \\
\hline MBVM1 & 0.25 & 0.11 & 0.14 \\
\hline MBVM3 & 0.06 & 0.01 & $\begin{array}{c}0.75) \\
(1.72)\end{array}$ \\
\hline
\end{tabular}

"'Significant at $10 \%$ level.

Table 7: Mean Value for Some Key Variables for the Compliance and Noncompliance Subsamples.

\begin{tabular}{|c|c|c|c|}
\hline Variable & $\begin{array}{c}\text { Parameter } \\
\text { Estimate } \\
\text { (Day 1 after IPO } \\
\text { started trading) }\end{array}$ & $\begin{array}{c}\text { Parameter } \\
\text { Estimate } \\
\text { (Month 1 after IPO } \\
\text { started trading) }\end{array}$ & $\begin{array}{c}\text { Parameter } \\
\text { Estimate } \\
\text { (Month 3 after IPO } \\
\text { started trading) }\end{array}$ \\
\hline Intercept & 10.83 & $4.82^{* *}$ & $0.45^{* *}$ \\
\hline CLVL & $(1.64)$ & $(2.44)$ & $(1.74)$ \\
\hline AGE & -0.27 & 0.19 & 0.04 \\
& $(-0.33)$ & $(0.80)$ & $(1.37)$ \\
\hline IOP & -0.01 & 0.00 & -0.00 \\
\hline LSIZE & $(-0.26)$ & $(0.35)$ & $(-0.32)$ \\
\hline PCTPUB & -0.90 & -0.09 & 0.06 \\
& $(-0.55)$ & $(-0.18)$ & $-0.94)$ \\
\hline AUDREP & $-0.47^{* *}$ & $-0.19 * *$ & $(-2.12)$ \\
\hline Adj. R ${ }^{2}$ & $(-1.99)$ & $(-2.70)$ & 0.12 \\
& $(2.82)$ & 0.35 & $(0.71)$ \\
\hline
\end{tabular}

'Significant at $1 \%$ level.

"Significant at $5 \%$ level.

** Significant at $10 \%$ level.

Table 8: Multivariate Analysis: Impact of Compliance on Value of the Firm in the Post-IPO Periods

Model: MBV $=\alpha_{0}+\beta_{1}$ CLVL $+\beta_{2}$ AGE $+\beta_{3}$ IOP $+\beta_{4}$ LSIZE $+\beta_{5}$ PCTPUB $+\beta_{6}$ AUDREP $+\varepsilon$

by December 31, 2001 and investigates whether the capital market can recognize the IPO firms that are in compliance from those that are not, using a sample of 72 IPO firms in Indonesia over the period 2002 through 2007. Results from the multivariate analysis indicate that IPO firms that are in compliance do experience significant less underpricing compared to those that are not. Furthermore, a positive, but insignificant, relationship between compliance and post-IPO firm valuation is reported in the present study.

The results documented in the present study are striking given the popular belief that the corporate governance mechanisms, installed over the years, in public companies of Indonesia may have failed and that the

resources and efforts were wasted primarily because the country lacks strong legal culture. With the results documented in the present study, policy makers in Indonesia and other developing economies, as well donor agencies involved in helping them to craft and implement good governance measures, can successfully fend off this type of criticisms and defend pursuing an aggressive agenda of governance reform while, possibly, pursuing legal reform simultaneously.

\section{References}

1. Hanafi (1997) Effisiensi Emisi Sahan Baru di Bursa Efek Jakarta.

2. Ali S, J Hartono (2003) Pengaruh Pemilihan Metode Akuntansi terhadap Tingkat Underpricing Saham Perdana, Jurnal Riset Akuntansi Indonesia 6: 41-53.

3. Loughran T, Ritter JR, Rydqvist K (1994) Initial Public Offerings: International Insights, Pacific-Basin Finance Journal 2: 165-199.

4. Ljungqvist $A, Y u X(2003)$ Stock Market Development, Liquidity and Corporate Governance, Working Paper, New York University.

5. Boulton TJ, Smart SB, Zutter CJ (2010) IPO Underpricing and Internationa Corporate Governance, Journal of International Business Studies 41: 1-38.

6. Kamal M (2008) The New Indonesian Company Law: Does it Support Good Corporate Governance? Macquarie Law School.

7. Ritter JR (1984) The Hot Issue Market of 1980, Journal of Business 57: 215240.

8. Ljungqvist A, WJ Wilhelm (2003) IPO Pricing in the Dot-Com Bubble, Journal of Finance 58: 723-752.

9. Leland H, Pyle DH (1977) Informational Asymmetries, Financial Structure, and Financial Intermediation. Journal of Finance 32: 371-387.

10. Downes DH, Heinkel R (1982) Signaling and the Valuation of Unseasoned New Issues. Journal of Finance 37: 1-10.

11. Clarkson PM, Dontoh A, Richardson G, Sefcik SE (1991) Retained Ownership and the Valuation of IPOs: Canadian Evidence. Contemporary Accounting Research 8: 115-131.

12. How J, Low JG (1993) Fractional Ownership and Underpricing: Signals of Firm Value. Pacific-Basin Finance Journal 1: 47-65.

13. Tinic SM (1988) Anatomy of Initial Public Offerings of Common Stock. Journal of Finance 43: 789-822.

14. Titman S, Trueman B (1986) Information Quality and the Valuation of New Issues. Journal of Accounting and Economics 8: 159-172. 